\title{
Reaction of soil enzymes and spring barley to copper chloride and copper sulphate
}

\author{
Jadwiga Wyszkowska $^{1}$ - Edyta Boros-Lajszner ${ }^{1}$ - Waldemar Lajszner ${ }^{1}$ • \\ Jan Kucharski ${ }^{1}$
}

Received: 24 June 2016/ Accepted: 31 May 2017/Published online: 7 June 2017

(c) The Author(s) 2017. This article is an open access publication

\begin{abstract}
Study was carried out to compare the effect of the degree of contamination of soil with copper on the soil enzyme activity, depending on the type of chemical compound with which a metal reaches the soil and on the method of soil use. An effect of increasing doses of copper on growth and the development of spring barley has been studied. The study was carried out as a pot experiment on two types of soil: loamy sand and light loam. Copper was introduced to soil as copper(II) sulphate(VI) and copper(II) chloride at four doses: 150, 300, 450 and $600 \mathrm{mg} \mathrm{Cu}{ }^{2+}$ $\mathrm{kg}^{-1}$ d.m. of soil. Soil without copper was used as a control sample. The experiment showed that contamination of soil with copper applied as $\mathrm{CuCl}_{2}$ and $\mathrm{CuSO}_{4} \cdot 5 \mathrm{H}_{2} \mathrm{O}$ upset the homeostasis of soil. Dehydrogenases and urease were the most sensitive to contamination of soil with $\mathrm{Cu}^{2+}$, both as copper(II) chloride and as copper(II) sulphate(VI), and acid phosphatase and alkaline phosphatase were the least sensitive. Greater changes in enzymatic activity were observed in loamy sand than in light loam. The differences in the impact of copper(II) sulphate(VI) and copper(II) chloride on the soil microbiome were relatively small, because mean $\mathrm{ED}_{50}$ for copper(II) chloride was $341 \mathrm{mg} \mathrm{\textrm {Cu } ^ { 2 + }}$ $\mathrm{kg}^{-1}$ d.m. of soil, and for copper(II) sulphate(VI) it was $364 \mathrm{mg} \mathrm{Cu}{ }^{2+} \mathrm{kg}^{-1} \mathrm{~d}$.m. of soil. This inhibitory effect of copper persisted throughout the period of the experiment. The sensitivity of spring barley to copper compounds was lower than the enzymes under study.
\end{abstract}

Jadwiga Wyszkowska

jadwiga.wyszkowska@uwm.edu.pl

1 Department of Microbiology, University of Warmia and Mazury, Plac Łódzki 3, 10-727 Olsztyn, Poland
Keywords Copper - Soil - Soil enzymes - Spring barley · Soil resistance

\section{Introduction}

Copper is one of the oldest metals known to man, and its deposits were excavated as early as around $1500 \mathrm{BC}$ (Tica et al. 2011). Copper occurs at oxidation states $+1,+2,+3$ and +4 . Solubility of salts of copper at +1 is lower than those of copper at +2 . Soluble copper compounds include: $\mathrm{CuSO}_{4}, \mathrm{Cu}\left(\mathrm{NO}_{3}\right)_{2}, \mathrm{Cu}\left(\mathrm{CH}_{3} \mathrm{COO}\right)_{2}$. Copper compounds of low solubility include: $\mathrm{CuCl}_{2}, \mathrm{CuCO}_{3}, \mathrm{CuS}, \mathrm{Cu}_{2} \mathrm{~S}$, $\mathrm{Cu}(\mathrm{OH})_{2}, \mathrm{Cu}\left(\mathrm{PO}_{4}\right)_{2}, \mathrm{Cu}_{2} \mathrm{O}$ and $\mathrm{CuO} . \mathrm{Cu}^{2+}$ ions in aqueous solutions have a characteristic blue colour. This is caused by the formation of $\mathrm{Cu}\left(\mathrm{H}_{2} \mathrm{O}\right)_{4}^{2+}$ complex. The most common copper salts include copper(II) chloride, copper(II) sulphate(VI) and copper(II) nitrate(V). Anhydrous copper(II) chloride is used as a laboratory reagent; it is also used in metallurgy, in ceramics manufacturing, in electroplating and in the production of tree protection agents. Copper(II) sulphate(VI) is used in electroplating, in data transmission, in fabric printing and in the production of insecticides and herbicides to colour brass and zinc products (Wang et al. 2010). Both copper compounds are salts of strong acids with different degrees of dissociation.

Although copper is a heavy metal, it is also a biogenic element, which means that it is essential in organism function (Hu et al. 2013). This element is commonly found in the Earth's crust, and its average content ranges from 5 to $100 \mathrm{mg} \mathrm{kg}^{-1}$. In nature, it is found both in a free state and in combination with other elements, typically with oxygen and sulphur. The most important copper ores include: chalcopyrite $\mathrm{CuFeS}_{2}$, cuprite $\mathrm{Cu}_{2} \mathrm{O}$, chalcocite $\mathrm{Cu}_{2} \mathrm{~S}$ and malachite $\mathrm{CuCO}_{3} \cdot \mathrm{Cu}(\mathrm{OH})_{2}$ (Kabata-Pendias 
2004). The total copper content of soils in Poland ranges from 1.53 to $271.73 \mathrm{mg} \mathrm{kg}^{-1}$ of soil (Kabata-Pendias and Pendias 2001). The average copper content of soils in the world is as follows: in Tibet-China, it ranges from 13.1 to $495.9 \mathrm{mg} \mathrm{kg}^{-1}$ (Zhang et al. 2010); in Botswana, Republic of South Africa, it ranges from 20 to $372 \mathrm{mg} \mathrm{kg}^{-1}$ (Ngole and Ekosse 2012); and in Australia, it ranges from 11 to $320 \mathrm{mg} \mathrm{kg}^{-1}$ (Wightwick et al. 2008). However, when excessive amounts of copper are present in soil, it can disrupt its basic functions. The main sources of contamination of soil with copper include: industrial emissions, especially close to areas of mining and metal industry, mineral and organic fertilisers, plant protection agents and communal waste, especially in highly industrialised towns (Yang et al. 2006).

Excessive levels of copper in soil can inhibit its enzymatic activity. According to Wang et al. (2009), this process occurs in several ways: (a) by directly affecting microorganisms and enzymes that they produce, (b) by binding active protein groups of an enzyme, (c) by forming a substrate complex, (d) as a result of reaction with the enzyme-substrate complex. The effects of copper on soil enzymes may result from the penetration of metal ions into microorganism cells, or their adsorption on the cell surfaces (Fernandez-Calvino et al. 2010a). The amount of the element penetrating into a cell is also determined by the permeability of the cytoplasmic membrane. A significant role in the penetration of metal ions into microorganism cells and their adsorption on their surface is played by bacterial mucus, whose amount and composition depend on the microorganism species. The differences in microorganism responses to heavy metals result from the dissimilarity of the metabolites they generate, which may bond metals to form chelate complexes or permanent deposits (Wang et al. 2009).

Zhang et al. (2012) and Zhan and Sun (2014) claim that enzymatic activity is a good parameter to express potential soil contamination. Moreover, reducing the activity of soil enzymes can be a specific response to the toxic substances which appear in the ecosystems, such substances frequently being anthropogenic (Ciarkowska et al. 2014; Wyszkowski and Wyszkowska 2009).

Now, in the twenty-first century, when human interference with the environment (especially soil) has resulted in an increase in the amounts of this element in soil, often above the acceptable levels, copper is becoming dangerous to all living organisms. Kungolos et al. (2009) studied the effects of copper chloride on the soil biological activity, and Khalil et al. (2015) studied the effects of copper sulphate. There are no reports comparing the effect of the degree of contamination of soil with copper on the soil microbiome depending on the type of chemical compound in which this element reaches the soil. Therefore, in order to demonstrate whether the type of a chemical compound-a source of soil contamination with copper-affects the biochemical stability, the effect of copper chloride and copper sulphate on the enzymatic activity and on the growth of spring barley was compared.

\section{Materials and methods}

\section{Setting up the experiment}

The experiment was carried out in a vegetation hall owned by the University of Warmia and Mazury. Soil samples were taken from the surface layer of arable land at a depth of $0-20 \mathrm{~cm}$ at the Teaching and Research Station situated in Tomaszków in the Olsztyn Lake District, with proper brown soil and leached brown soil dominating (north-east of Poland, $53.7161^{\circ} \mathrm{N}, 20.4167^{\circ} \mathrm{E}$ ). Loamy sand and light loam were used in the experiment. Based on the World Reference Base of Soil Resources (2014), they were classified as Eutric Cambisols. The physicochemical properties of the soils are presented in Table 1.

The experiment was set up in plastic pots, with $3 \mathrm{~kg}$ of loamy sand and light loam. Copper was then applied to the soils in the form of copper chloride and copper sulphate in the following doses $\left(\mathrm{mg} \mathrm{kg}^{-1}\right): 150,300,450$ and 600. The control was the soil with no copper added. Converted to amounts of a pure component, fertilisation amounted to $\left(\mathrm{mg} \mathrm{kg}^{-1}\right)$ : nitrogen-100, phosphorus-44, potassium125, magnesium-20, zinc - 5, manganese -5 , molybdenum-5, boron- 0.33 . After thorough mixing of the soil samples with the copper compounds and fertilisers, their humidity was adjusted to the level of $50 \%$ of capillary water capacity and was maintained at this level for the entire duration of the experiment. Twenty-four hours after the establishment of the experiment, half of the pots were sown and the other half were not. Spring barley (Hordeum vulgare L.), Rabel cultivar, was the plant under test (12 plants were left per pot after germination); it was harvested when $20 \%$ of panicles emerged (phase BBCH 52). On days $14,28,42$ and 56 of the incubation in the unsown soil and the soil sown with spring barley, the activity of soil enzymes was determined.

\section{Enzymes soil}

Activity of dehydrogenases [EC 1.1], urease [EC 3.5.1.5], acid phosphatase [EC 3.1.3.2] and alkaline phosphatase [EC 3.1.3.1] was determined in soil samples on day 14, 28, 42 and 56 of incubation. Dehydrogenases were determined by the method developed by Öhlinger (1996), urease was determined by the method developed by Alef et al. (1998), and acid phosphatase, alkaline phosphatase-by the 
Table 1 Some physicochemical properties of soils used in the experiment

\begin{tabular}{|c|c|c|c|c|c|c|c|c|}
\hline \multirow[t]{2}{*}{ Type of soil } & \multicolumn{3}{|c|}{ Granulometric composition (mm) } & \multirow[t]{2}{*}{$\mathrm{pH}_{\mathrm{KCl}}$} & \multirow{2}{*}{\multicolumn{2}{|c|}{$\begin{array}{lr}\text { HAC } & \text { EBC } \\
\left(\mathrm{mmol}^{(+)} \mathrm{kg}^{-1} \text { soil }\right)\end{array}$}} & \multirow[t]{2}{*}{$\mathrm{C}_{\text {org }}\left(\mathrm{g} \mathrm{kg}^{-1}\right)$} & \multirow[t]{2}{*}{$\mathrm{Cu}\left(\mathrm{mg} \mathrm{kg}^{-1}\right)$} \\
\hline & $2-0.05$ & $0.05-0.002$ & $<0.002$ & & & & & \\
\hline LS & 79 & 19 & 2 & 6.90 & 11.25 & 89.30 & 7.50 & 2.50 \\
\hline LL & 64 & 28 & 8 & 7.00 & 8.77 & 159.00 & 11.15 & 3.60 \\
\hline
\end{tabular}

$L S$ loamy sand, $L L$ light loam, $H A C$ hydrolytic acidity, $E B C$ exchangeable base cations, $C_{\text {org }}$ organic carbon content, $C u$ available copper content

procedures described by Alef and Nannipieri (1998). The activity of dehydrogenases was expressed in $\mu \mathrm{mol}$ TFF kg ${ }^{-1}$ d.m. $\mathrm{h}^{-1}$, urease-in mmol N-NH $\mathrm{kg}^{-1}$ d.m. $\mathrm{h}^{-1}$, and acid phosphatase and alkaline phosphatase in mmol PNP kg ${ }^{-1}$ d.m. $\mathrm{h}^{-1}$. All enzymes were determined with a PerkinElmer Lambda 25 spectrophotometer (Massachusetts, USA). The activity of dehydrogenases was measured at the wavelength of $\lambda=485 \mathrm{~nm}$ and that of urease, acid phosphatase and alkaline phosphatase-at $\lambda=410 \mathrm{~nm}$. Moreover, indexes of resistance (RS) of each enzyme to soil contamination with copper were calculated (Orwin and Wardle 2004).

\section{Statistical analysis}

The results were analysed statistically with an analysis of variance by means of Statistica 12.5 software (StatSoft and Inc 2015), by determining the homogeneous groups with a Tukey test, at the level of confidence of $p=0.05$. The activity of enzymes in soil contaminated with copper was analysed by means of principal component analysis (PCA) with multidimensional exploration techniques. Additionally, Pearson's correlation coefficient was calculated between the dose of copper and the resistance of the enzymes under study. The percentile variability of all analysed variables was determined by calculating the $\eta^{2}$ coefficient in the analysis of variance-ANOVA. Moreover, $\mathrm{ED}_{50}$ was calculated for each enzyme and the spring barley yield.

\section{Results}

The activity of dehydrogenases and urease was affected to the greatest extent by the degree of contamination of soil with copper; the activity of alkaline phosphatase by the type of soil formation; and the activity of acid phosphatase by the time of soil incubation (Table 2).

The effect of the degree of contamination of soil with copper on the activity of soil enzymes was interpreted by means of principal component analysis (PCA) (Figs. 1, 4). The application of PCA was based on the fact that there were a large number of internally connected factors
Table 2 Percentage share of observed variability factors $\eta^{2}$

\begin{tabular}{lrrrr}
\hline Variable factors & \multicolumn{5}{l}{ Enzymes } & & \\
\cline { 2 - 5 } & \multicolumn{1}{c}{ Deh } & \multicolumn{1}{c}{ Ure } & \multicolumn{1}{c}{ Pac } & \multicolumn{1}{c}{ Pal } \\
\hline Dose $\mathrm{Cu}^{2+}$ & 62.341 & 37.145 & 10.653 & 32.707 \\
Type of $\mathrm{Cu}^{2+}$ compound & 0.391 & 0.119 & 0.099 & 0.086 \\
Type of soil & 1.089 & 26.943 & 3.370 & 46.251 \\
Soil use & 14.541 & 0.608 & 5.739 & 2.067 \\
Soil incubation time & 1.229 & 4.387 & 12.375 & 0.906 \\
\hline
\end{tabular}

Deh dehydrogenases, Ure urease, Pac acid phosphatase, Pal alkaline phosphatase

(5-factorial experiment) and the relations between them could arise from the existence of one or more common factors. PCA allowed to determine precisely and accurately the scale of biochemical changes which occurred in soil because of the presence of the contamination under study.

The distribution of vectors around the axis which represents the first factor in soil contaminated by copper(II) sulphate(VI) and copper(II) chloride is described by 86.41 and $88.09 \%$ of the total variance of data, respectively (Fig. 1a, b). The activity of soil enzymes correlated negatively with the first principal component, regardless of the type of copper salt. Vectors which map the primary variables are arranged in a similar manner for contamination with copper(II) sulphate and copper(II) chloride. Their position proves the occurrence of the response of acid phosphatase, alkaline phosphatase and urease to contamination with $\mathrm{Cu}^{2+}$. Dehydrogenases correlated slightly less with these enzymes. When projected onto a plane, these cases prove that a reaction of all enzymes to $\mathrm{Cu}^{2+}$ was strongly negative. Copper was a strong inhibitor of all the enzymes, regardless of the type of compound and type of soil. This is also proven by the cases shown in Fig. 2. The effect of copper(II) chloride and copper(II) sulphate(VI) on enzymes in both soils was similar. In particular, the position of individual cases showing the effect of copper(II) sulphate(VI) and copper(II) chloride was nearly identical at all levels of contamination. The contents of available copper in both soils were similar, i.e., for loamy sand it ranged from 131.6 in pots contaminated with $150 \mathrm{mg} \mathrm{Cu}^{2+}$ 


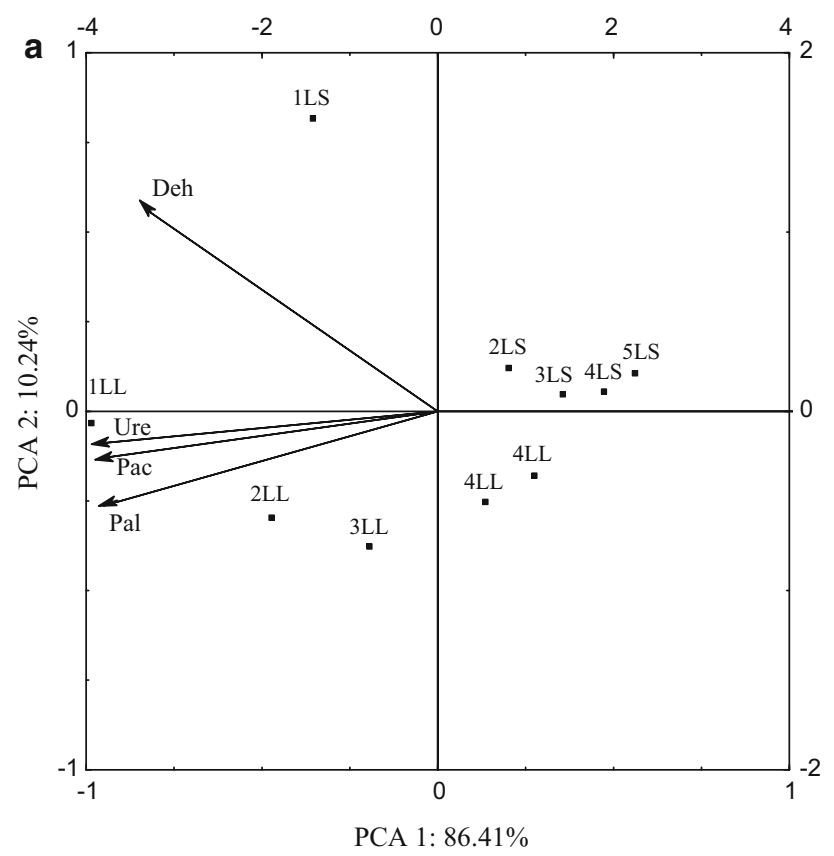

Fig. 1 Activity of enzymes in soil contaminated with copper chloride (a) and copper sulphate (b) depending on the dose of copper and soil type as presented by the PCA method. Soil enzymes: Deh dehydrogenases, Ure urease, Pac acid phosphatase, Pal alkaline phosphatase.

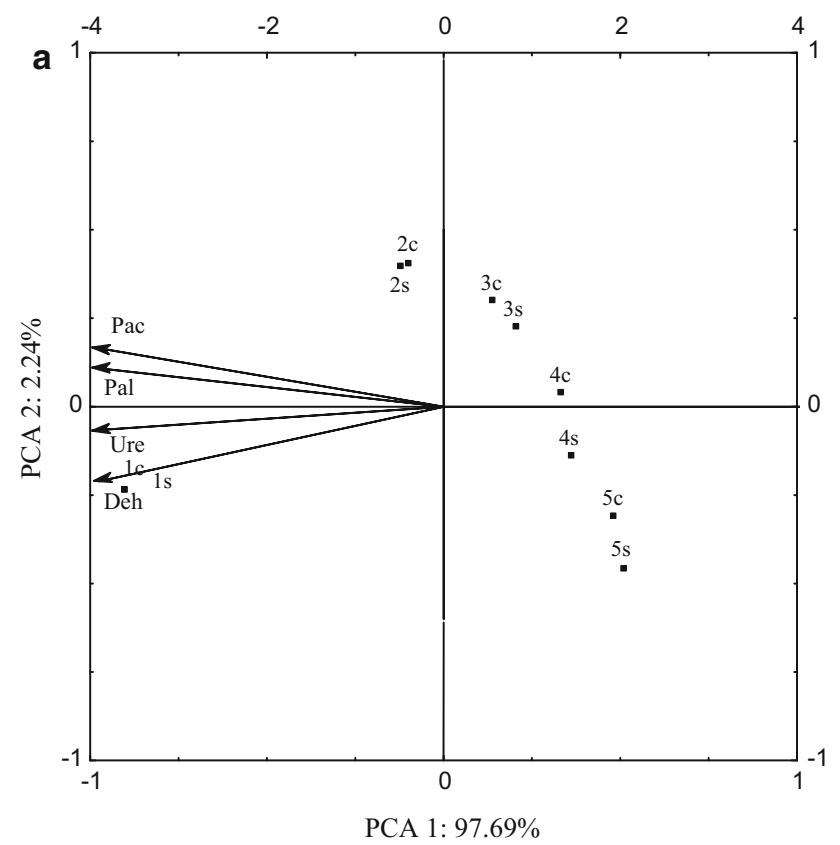

Fig. 2 Activity of enzymes in loamy sand (a) and in light loam (b) contaminated with copper depending on the dose of copper and the compound as presented by the PCA method. Soil enzymes: Deh dehydrogenases, Ure urease, Pac acid phosphatase, Pal alkaline

$\mathrm{kg}^{-1}$ of soil to $563.5 \mathrm{mg} \mathrm{kg}^{-1}$ in pots contaminated with $600 \mathrm{mg} \mathrm{Cu}^{2+} \mathrm{kg}^{-1}$ of soil and, and for light loam, it ranged from 133.2 to $564.8 \mathrm{mg} \mathrm{kg}^{-1}$, respectively.

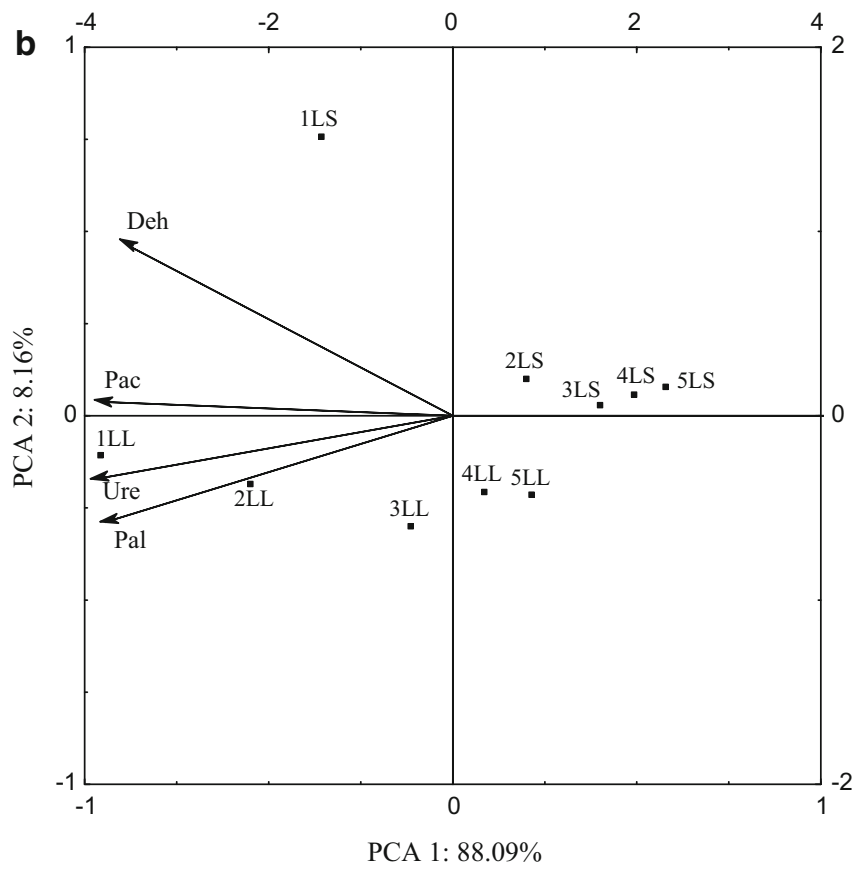

Dose $\mathrm{Cu}^{2+} \mathrm{mg} \mathrm{kg}^{-1}$ of soil: $1-0 \mathrm{mg} ; 2-150 \mathrm{mg}$; $3-300 \mathrm{mg}$; $4-$ $450 \mathrm{mg}, 5-600 \mathrm{mg}$. Type of soil: $L S$ loamy sand, $L L$ light loam

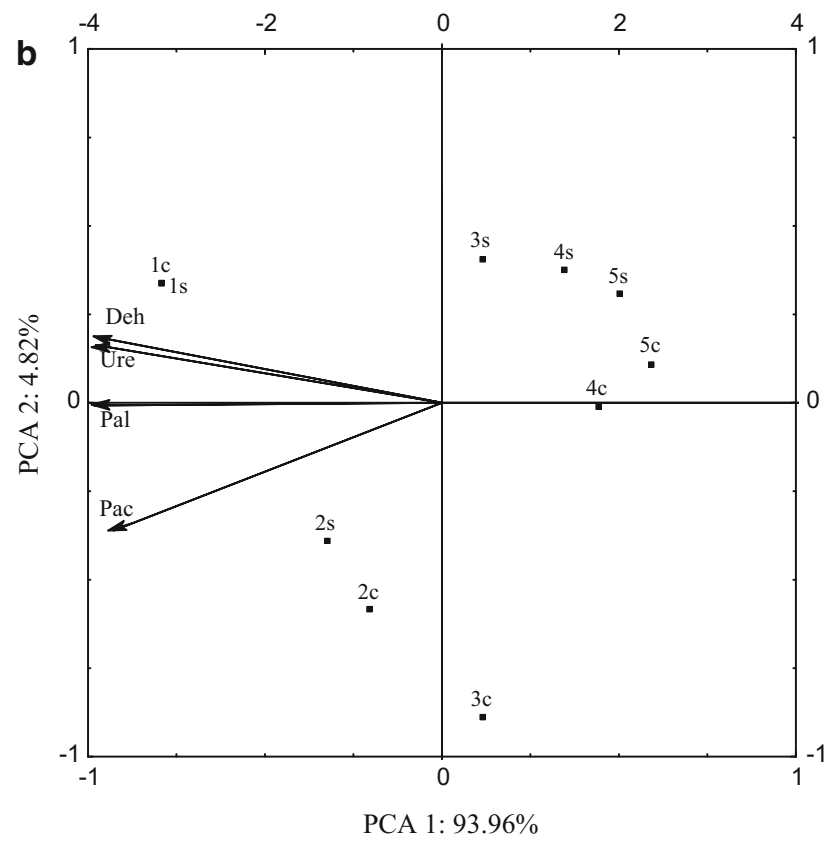

phosphatase. Dose $\mathrm{Cu}^{2+} \mathrm{mg} \mathrm{kg}^{-1}$ of soil: $1-0 \mathrm{mg}$; $2-150 \mathrm{mg}$; $3-300 \mathrm{mg}$; 4-450 mg, 5-600 mg. Type of $\mathrm{Cu}^{2+}$ compound: c-copper(II) chloride, s-copper(II) sulphate(VI)

Regardless of the soil type (Fig. 3), this thesis is supported by cases situated next to each other for the effect of each level of contamination with copper(II) sulphate(VI) 


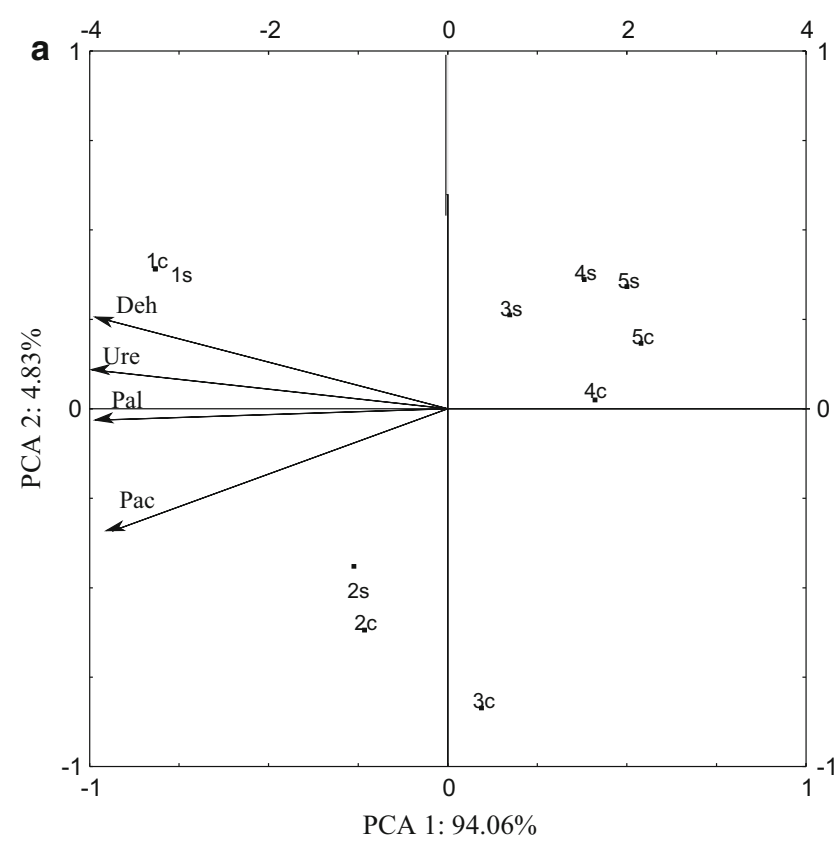

Fig. 3 Activity of enzymes in sown (a) and unsown (b) soil contaminated with copper depending on the dose of copper and the compound as presented by the PCA method. Soil enzymes: Deh dehydrogenases, Ure urease, Pac acid phosphatase, Pal alkaline

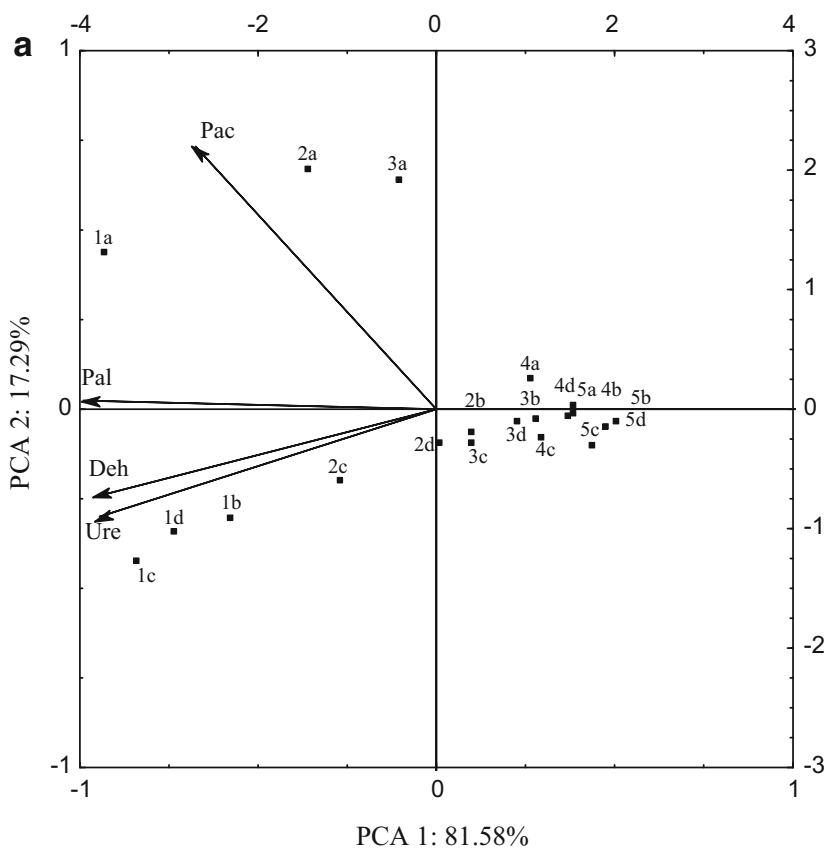

Fig. 4 Activity of enzymes in soil contaminated with copper chloride (a) and copper sulphate (b) depending on the dose of copper and duration of the experiment as presented by the PCA method. Soil enzymes: Deh dehydrogenases, Ure urease, Pac acid phosphatase,

and copper(II) chloride. This position was similar, in both the soil sown with spring barley and not sown at all. A negative effect of copper on soil enzymes persisted throughout the experiment (Fig. 4), i.e., for 56 days.

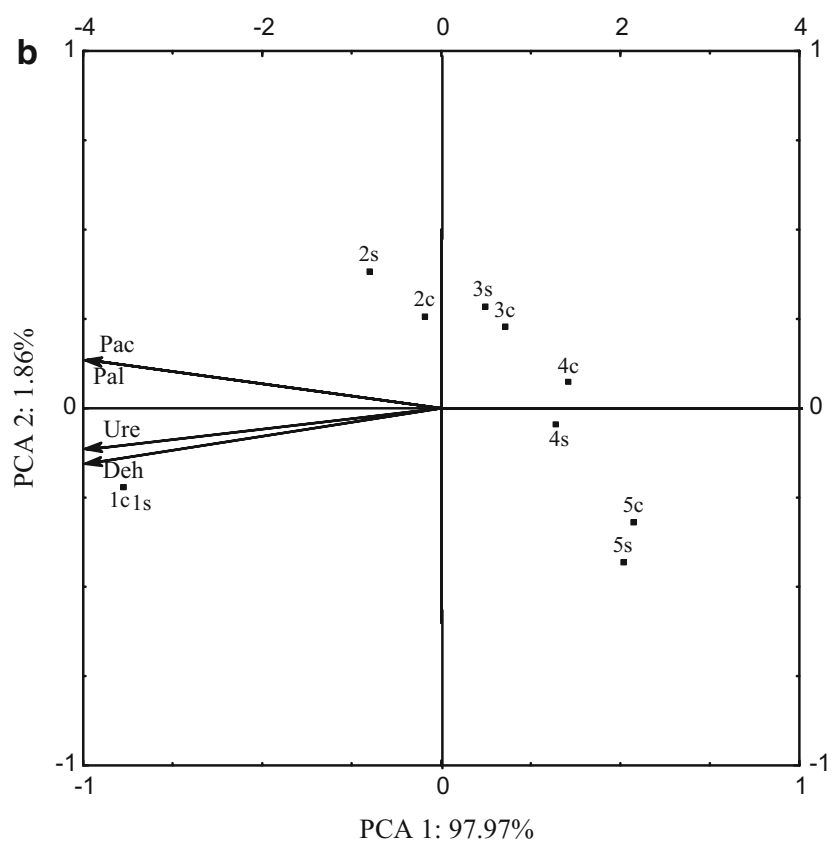

phosphatase. Dose $\mathrm{Cu}^{2+} \mathrm{mg} \mathrm{kg}^{-1}$ of soil: $1-0 \mathrm{mg}$; 2-150 mg; 3$300 \mathrm{mg} ; 4-450 \mathrm{mg}, 5-600 \mathrm{mg}$. Type of $\mathrm{Cu}^{2+}$ compound: $\mathrm{c}-$ copper(II) chloride, s-copper(II) sulphate(VI)



Pal alkaline phosphatase. Dose $\mathrm{Cu}^{2+} \mathrm{mg} \mathrm{kg}^{-1}$ of soil: $1-0 \mathrm{mg}$; $2-$ $150 \mathrm{mg}$; 3-300 mg; 4-450 mg, 5-600 mg. Soil incubation time: $\mathrm{a}-14$ days; $\mathrm{b}-28$ days; $\mathrm{c}-42$ days; $\mathrm{d}-56$ days

As with soil enzymes, the type of a copper compound did not have any effect on the growth of spring barley (Fig. 5). The plant growth was significantly disrupted by a dose of $\mathrm{Cu}^{2+}$ of more than $150 \mathrm{mg} \mathrm{kg}^{-1} \mathrm{~d}$.m. of soil, and 
even this dose had an inhibitory effect on the enzymes. Unlike with soil enzymes, there was a great difference in the reaction of spring barley grown on loamy sand and on light loam. High levels of contamination with $\mathrm{Cu}^{2+}$ (300-600 $\mathrm{mg} \mathrm{kg}^{-1} \mathrm{~d}$.m. of soil) were tolerated better by spring barley grown on loamy sand than on light loam. This is reflected in the dose of copper, which reduced the yield of spring barley by $50 \%$ (Figs. 6, 7). In loamy sand, it was $238 \mathrm{mg} \mathrm{Cu}{ }^{2+} \mathrm{kg}^{-1}$ d.m. of soil, applied as copper(II) chloride and $195 \mathrm{mg} \mathrm{Cu}^{2+} \mathrm{kg}^{-1}$ d.m. of soil, applied as copper(II) sulphate(VI). $\mathrm{ED}_{50}$ for spring barley grown on light loam was: $590 \mathrm{mg} \mathrm{Cu}{ }^{2+} \mathrm{kg}^{-1}$ d.m. of soil applied as copper(II) chloride and more than $600 \mathrm{mg} \mathrm{Cu}^{2+} \mathrm{kg}^{-1}$ d.m. of soil, applied as copper(II) sulphate(VI).

$\mathrm{ED}_{50}$ for activity of different enzymes varied depending on the type of soil (Fig. 6), type of copper compound (Fig. 7) and the method of soil use (Fig. 8). Regardless of these variables, dehydrogenases and urease were the most sensitive to contamination of soil with $\mathrm{Cu}^{2+}$, both as copper(II) chloride and as copper(II) sulphate(VI), and acid phosphatase and alkaline phosphatase were the least sensitive.
Although the type of chemical compound used to introduce copper to soil had the smallest impact on a change in biochemical activity of soil, it had a significant impact on the stability of soil, as measured by the activity of soil enzymes. Resistance of dehydrogenases, urease (Table 3), acid phosphatase and alkaline phosphatise (Table 4) in loamy sand and light loam contaminated with copper(II) chloride and copper(II) sulphate(VI), both sown and not sown with spring barley, was negatively correlated with the degree of contamination of soil with $\mathrm{Cu}^{2+}$. In general, regardless of the independent variables, resistance of dehydrogenases to contamination with copper(II) sulphate(VI) was higher by $28 \%$ than to contamination with copper(II) chloride, that of urease-by $16 \%$, that of acid phosphatase-by $67 \%$ and that of alkaline phosphataseby $14 \%$. Such unambiguous relationships were not found when resistance of soil enzymes to copper was analysed depending on the type of soil formation. In general, dehydrogenases and alkaline phosphatase was more stable in light loam than in loamy sand, and the opposite was true of urease and alkaline phosphatase. Sowing the soils with spring barley had a very positive effect on the
Fig. 5 Yield of spring barley from soil contaminated with copper. a loamy sand, $\mathrm{CuCl}_{2}$; b loamy sand, $\mathrm{CuSO}_{4} \cdot 5 \mathrm{H}_{2} \mathrm{O}$; c light loam, $\mathrm{CuCl}_{2}$; d light loam, $\mathrm{CuSO}_{4} \cdot 5 \mathrm{H}_{2} \mathrm{O}$
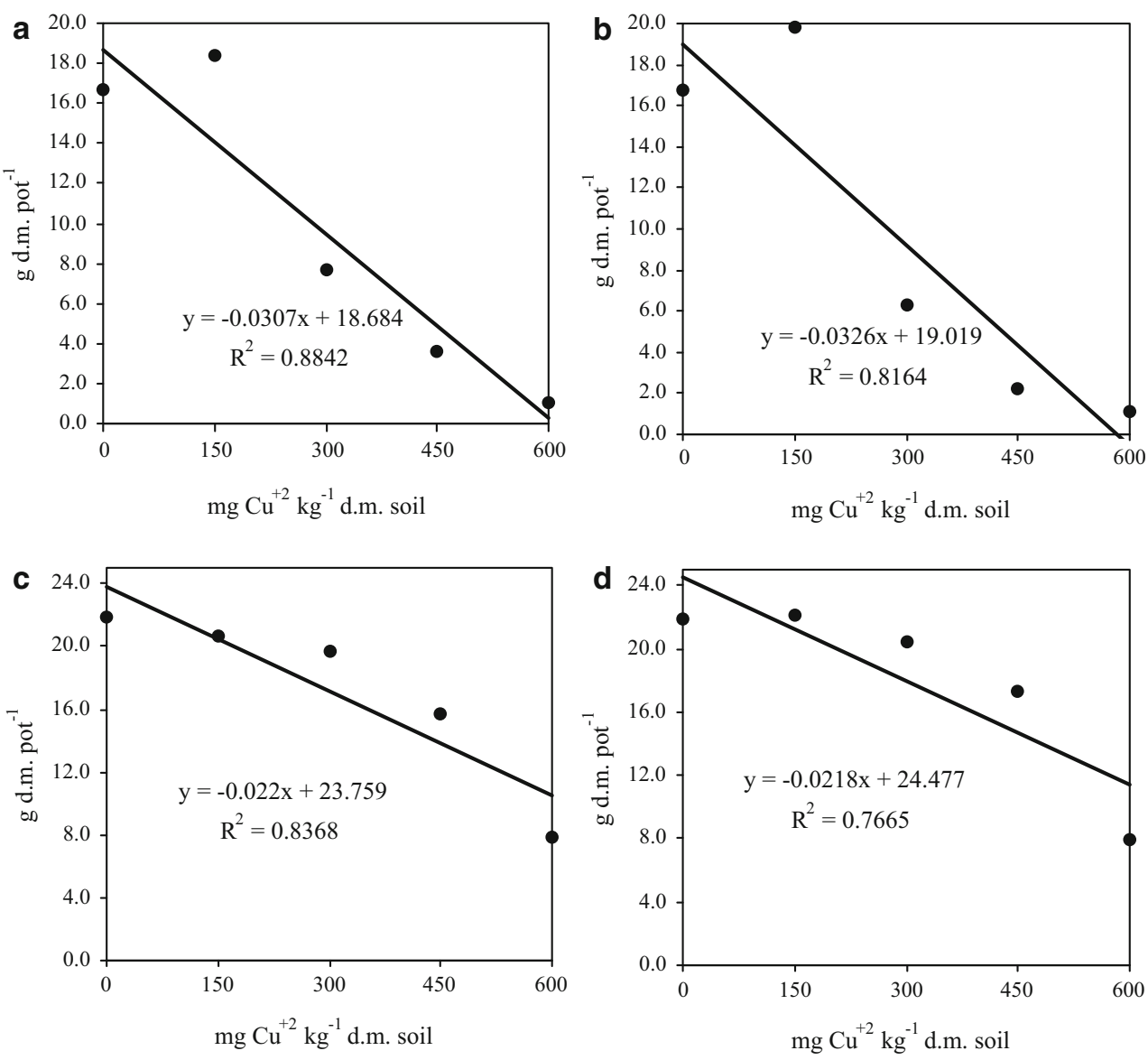

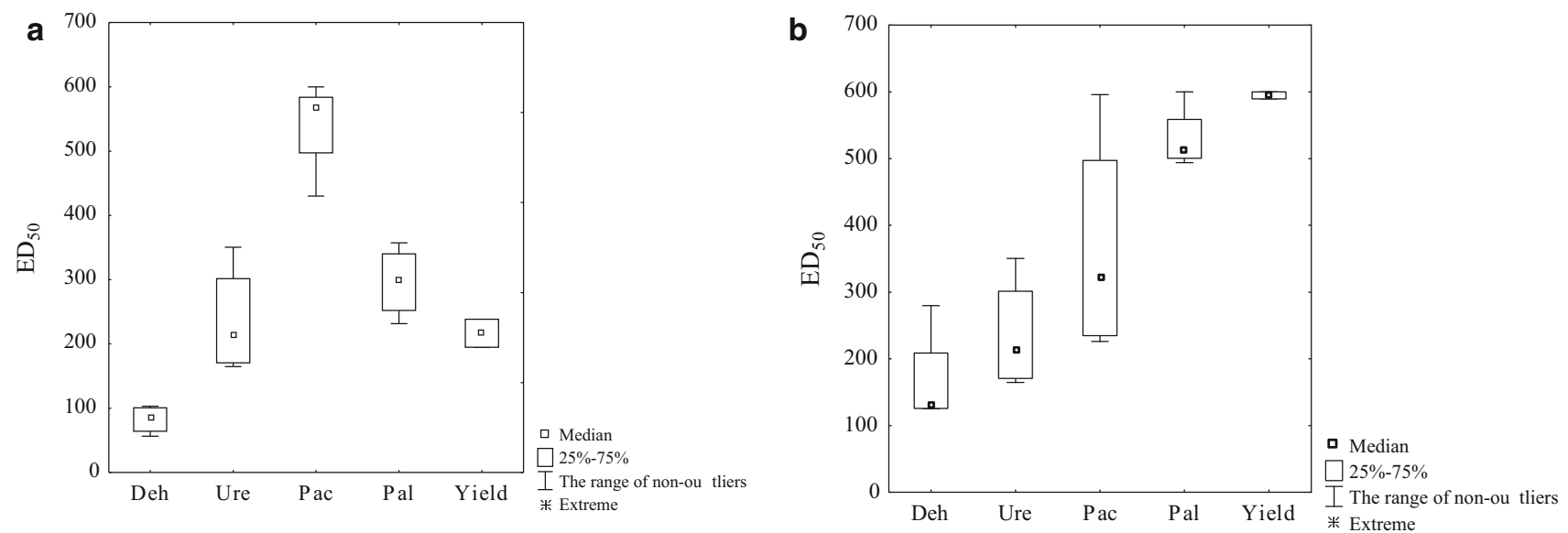

Fig. $6 \mathrm{ED}_{50}$ for enzyme activity and plant yield depending on the soil type a loamy sand, b light loam. Deh dehydrogenases, Ure urease, Pac acid phosphatase, $\mathrm{Pal}$ alkaline phosphatase
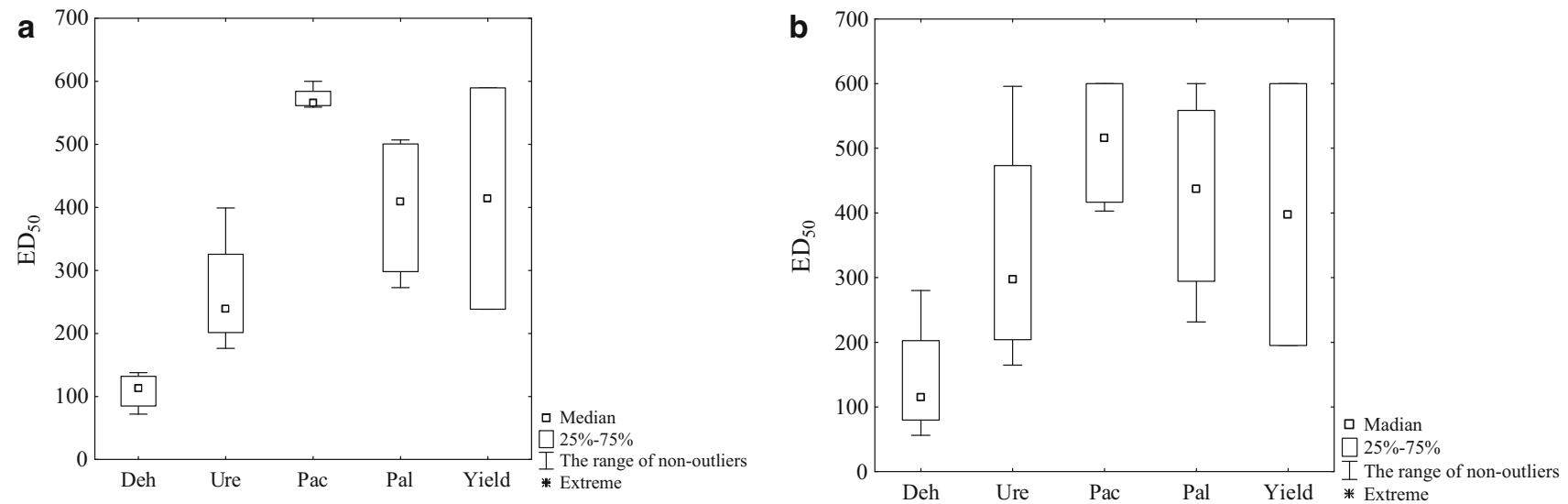

Fig. $7 \mathrm{ED}_{50}$ for enzyme activity and plant yield depending on the compound type a copper(II) chloride, b copper(II) sulphate(VI). Deh dehydrogenases, Ure urease, Pac acid phosphatase, Pal alkaline phosphatase
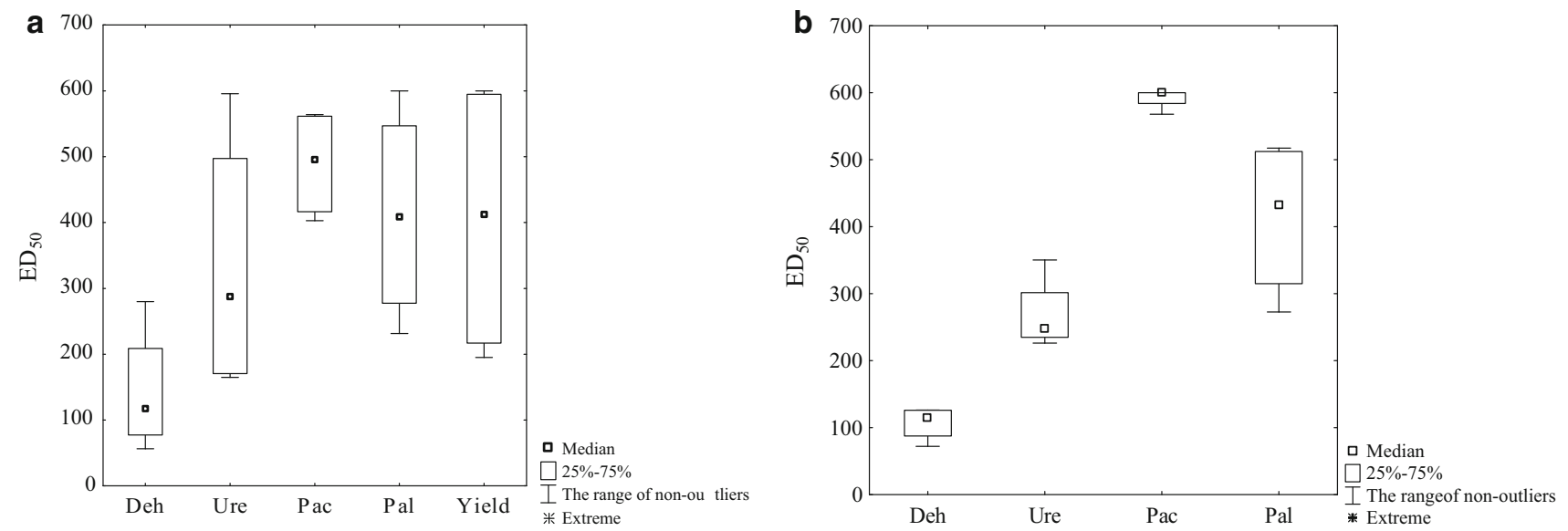

Fig. $8 \mathrm{ED}_{50}$ for enzyme activity and plant yield depending on the method of soil use: a sown soil, b unsown soil. Deh dehydrogenases, Ure urease, $\mathrm{Pac}$ acid phosphatase, $\mathrm{Pal}$ alkaline phosphatase

stability of the soil ecosystem. The resistance index for all enzymes was higher in the soil sown with spring barley than in the unsown soil. Root secretions of the plants had the most beneficial effect on RS of acid phosphatase (increase in resistance by $80 \%$ compared to unsown soil) and of dehydrogenases (increase in resistance by $73 \%$ ), and it 
Table 3 Resistance (RS) of dehydrogenases and urease in soil contaminated with copper

\begin{tabular}{|c|c|c|c|c|c|c|c|c|}
\hline \multirow{4}{*}{$\begin{array}{l}\text { Dose } \mathrm{Cu}^{+2} \\
\left(\mathrm{mg} \mathrm{kg}^{-1} \text { soil) }\right.\end{array}$} & \multicolumn{8}{|l|}{ Soil use } \\
\hline & \multicolumn{2}{|c|}{ Sown soil } & \multicolumn{2}{|c|}{ Unsown soil } & \multicolumn{2}{|l|}{ Sown soil } & \multicolumn{2}{|c|}{ Unsown soil } \\
\hline & \multicolumn{8}{|c|}{ Type of soil } \\
\hline & $\begin{array}{l}\mathrm{LS} \\
\mathrm{CuCl}_{2}\end{array}$ & LL & LS & LL & $\begin{array}{l}\mathrm{LS} \\
\mathrm{CuSO}_{4} \cdot 5 \mathrm{H}_{2} \mathrm{O}\end{array}$ & LL & LS & LL \\
\hline & \multicolumn{8}{|c|}{ Dehydrogenases } \\
\hline 150 & $0.221^{\mathrm{a}}$ & $0.477^{\mathrm{a}}$ & $0.093^{\mathrm{a}}$ & $0.260^{\mathrm{a}}$ & $0.138^{\mathrm{a}}$ & $0.422^{\mathrm{a}}$ & $0.294^{\mathrm{a}}$ & $0.264^{\mathrm{a}}$ \\
\hline 300 & $0.176^{\mathrm{b}}$ & $0.174^{\mathrm{b}}$ & $0.023^{\mathrm{b}}$ & $0.125^{\mathrm{b}}$ & $0.039^{\mathrm{b}}$ & $0.282^{\mathrm{b}}$ & $0.111^{\mathrm{b}}$ & $0.094^{\mathrm{b}}$ \\
\hline 450 & $0.053^{\mathrm{c}}$ & $0.085^{\mathrm{c}}$ & $0.000^{\mathrm{c}}$ & $0.047^{\mathrm{c}}$ & $0.031^{\mathrm{c}}$ & $0.180^{\mathrm{c}}$ & $0.059^{\mathrm{c}}$ & $0.037^{\mathrm{c}}$ \\
\hline 600 & $0.024^{\mathrm{d}}$ & $0.050^{\mathrm{d}}$ & $0.000^{\mathrm{c}}$ & $0.011^{\mathrm{d}}$ & $0.023^{\mathrm{c}}$ & $0.115^{\mathrm{d}}$ & $0.012^{\mathrm{d}}$ & $0.016^{\mathrm{d}}$ \\
\hline \multirow[t]{2}{*}{$r^{*}$} & -0.971 & -0.911 & -0.886 & -0.966 & -0.846 & -0.987 & -0.939 & -0.920 \\
\hline & Urease & & & & & & & \\
\hline 150 & $0.620^{\mathrm{a}}$ & $0.564^{\mathrm{a}}$ & $0.388^{\mathrm{a}}$ & $0.301^{\mathrm{a}}$ & $0.590^{\mathrm{a}}$ & $0.520^{\mathrm{a}}$ & $0.893^{\mathrm{a}}$ & $0.279^{\mathrm{a}}$ \\
\hline 300 & $0.465^{\mathrm{b}}$ & $0.459^{\mathrm{b}}$ & $0.355^{\mathrm{b}}$ & $0.179^{\mathrm{b}}$ & $0.362^{\mathrm{b}}$ & $0.424^{\mathrm{b}}$ & $0.527^{\mathrm{b}}$ & $0.214^{\mathrm{b}}$ \\
\hline 450 & $0.393^{\mathrm{c}}$ & $0.363^{\mathrm{c}}$ & $0.276^{\mathrm{c}}$ & $0.155^{\mathrm{c}}$ & $0.319^{\mathrm{c}}$ & $0.393^{\mathrm{b}}$ & $0.497^{\mathrm{b}}$ & $0.157^{\mathrm{c}}$ \\
\hline 600 & $0.355^{\mathrm{d}}$ & $0.341^{\mathrm{c}}$ & $0.117^{\mathrm{d}}$ & $0.133^{\mathrm{d}}$ & $0.315^{\mathrm{c}}$ & $0.350^{\mathrm{c}}$ & $0.339^{\mathrm{c}}$ & $0.154^{\mathrm{c}}$ \\
\hline$r^{*}$ & -0.956 & -0.969 & -0.953 & -0.908 & -0.857 & -0.968 & -0.932 & -0.947 \\
\hline
\end{tabular}

The same letters for an enzyme in columns are assigned to the same homogeneous groups

The significance of letters $\mathrm{a}, \mathrm{b}, \mathrm{c}, \mathrm{d}$ is $p=0.05$

* $r$ coefficient of correlation significant at $p=0.05, n=3$

$\mathrm{LS}$ loamy sand, $\mathrm{LL}$ light loam, $\mathrm{CuCl}_{2}$ copper(II) chloride, $\mathrm{CuSO}_{4} \cdot \mathrm{H}_{2} \mathrm{O}$ copper(II) sulphate(VI)

Table 4 Resistance (RS) of acid phosphatase and alkaline phosphatase in soil contaminated with copper

\begin{tabular}{|c|c|c|c|c|c|c|c|c|}
\hline \multirow[t]{4}{*}{ Dose $\mathrm{Cu}^{+2}\left(\mathrm{mg} \mathrm{kg}^{-1}\right.$ soil $)$} & \multicolumn{8}{|l|}{ Soil use } \\
\hline & \multicolumn{2}{|c|}{ Sown soil } & \multicolumn{2}{|c|}{ Unsown soil } & \multicolumn{2}{|l|}{ Sown soil } & \multicolumn{2}{|c|}{ Unsown soil } \\
\hline & \multicolumn{8}{|c|}{ Type of soil } \\
\hline & $\begin{array}{l}\mathrm{LS} \\
\mathrm{CuCl}_{2}\end{array}$ & LL & $\mathrm{LS}$ & LL & $\begin{array}{l}\mathrm{LS} \\
\mathrm{CuSO}_{4} \cdot 5 \mathrm{H}_{2} \mathrm{O}\end{array}$ & LL & LS & LL \\
\hline & \multicolumn{8}{|c|}{ Acid phosphatase } \\
\hline 150 & $0.703^{\mathrm{a}}$ & $0.959^{\mathrm{a}}$ & $0.721^{\mathrm{a}}$ & $0.805^{\mathrm{a}}$ & $0.693^{\mathrm{a}}$ & $0.888^{\mathrm{a}}$ & $0.786^{\mathrm{a}}$ & $0.783^{\mathrm{a}}$ \\
\hline 300 & $0.565^{\mathrm{b}}$ & $0.853^{\mathrm{b}}$ & $0.573^{\mathrm{b}}$ & $0.602^{\mathrm{b}}$ & $0.623^{\mathrm{b}}$ & $0.106^{\mathrm{b}}$ & $0.467^{\mathrm{c}}$ & $0.657^{\mathrm{b}}$ \\
\hline 450 & $0.443^{\mathrm{c}}$ & $0.121^{\mathrm{c}}$ & $0.569^{\mathrm{b}}$ & $0.607^{\mathrm{b}}$ & $0.488^{\mathrm{c}}$ & $0.088^{\mathrm{c}}$ & $0.581^{\mathrm{b}}$ & $0.528^{\mathrm{c}}$ \\
\hline 600 & $0.365^{\mathrm{d}}$ & $0.085^{\mathrm{d}}$ & $0.378^{\mathrm{c}}$ & $0.508^{\mathrm{c}}$ & $0.416^{\mathrm{d}}$ & $0.076^{\mathrm{d}}$ & $0.403^{\mathrm{d}}$ & $0.370^{\mathrm{d}}$ \\
\hline \multirow[t]{2}{*}{$r^{*}$} & -0.993 & -0.929 & -0.949 & -0.916 & -0.991 & -0.794 & -0.795 & -0.998 \\
\hline & \multicolumn{8}{|c|}{ Alkaline phosphatase } \\
\hline 150 & $0.623^{\mathrm{a}}$ & $0.782^{\mathrm{a}}$ & $0.451^{\mathrm{a}}$ & $0.570^{\mathrm{a}}$ & $0.467^{\mathrm{a}}$ & $0.685^{\mathrm{a}}$ & $0.533^{\mathrm{a}}$ & $0.632^{\mathrm{a}}$ \\
\hline 300 & $0.547^{\mathrm{b}}$ & $0.467^{\mathrm{b}}$ & $0.354^{\mathrm{b}}$ & $0.481^{\mathrm{b}}$ & $0.272^{\mathrm{b}}$ & $0.601^{\mathrm{b}}$ & $0.436^{\mathrm{b}}$ & $0.502^{\mathrm{b}}$ \\
\hline 450 & $0.375^{\mathrm{c}}$ & $0.302^{\mathrm{c}}$ & $0.221^{\mathrm{c}}$ & $0.372^{\mathrm{c}}$ & $0.219^{c}$ & $0.040^{\mathrm{c}}$ & $0.272^{\mathrm{c}}$ & $0.407^{\mathrm{c}}$ \\
\hline 600 & $0.240^{\mathrm{d}}$ & $0.260^{\mathrm{d}}$ & $0.176^{\mathrm{d}}$ & $0.333^{\mathrm{d}}$ & $0.180^{\mathrm{d}}$ & $0.031^{\mathrm{d}}$ & $0.182^{\mathrm{d}}$ & $0.308^{\mathrm{d}}$ \\
\hline$r^{*}$ & -0.990 & -0.943 & -0.985 & -0.985 & -0.926 & -0.924 & -0.993 & -0.997 \\
\hline
\end{tabular}

The same letters for an enzyme in columns are assigned to the same homogeneous groups

The significance of letters $\mathrm{a}, \mathrm{b}, \mathrm{c}, \mathrm{d}$ is $p=0.05$

* $r$ coefficient of correlation significant at $p=0.05, n=3$

$\mathrm{LS}$ loamy sand, $\mathrm{LL}$ light loam, $\mathrm{CuCl}_{2}$ copper(II) chloride, $\mathrm{CuSO}_{4} \cdot 5 \mathrm{H}_{2} \mathrm{O}$ copper(II) sulphate(VI) 
had the least beneficial effect on RS of alkaline phosphatase (an increase in resistance by $49 \%$ ) and urease (increase by $38 \%$ ).

\section{Discussion}

Copper is a heavy metal, which-after exceeding a threshold value - can have a harmful effect on the microbiological and biochemical properties of soil (Kucharski and Wyszkowska 2004; Zhang et al. 2012; Tripathy et al. 2014) and can also have a negative effect on plant growth (Zhang et al. 2014). These disruptions have been observed in this study. Each of the doses of $150-600 \mathrm{mg} \mathrm{Cu}^{2+} \mathrm{kg}^{-1}$ of soil disrupted the enzymatic activity of soil, with the strongest disruptions observed in dehydrogenases, which proves that the microbiological properties of soil were upset, because dehydrogenases are intracellular enzymes and microorganisms are their main source. According to Wang et al. (2007), copper applied in the amount of $658 \mathrm{mg} \mathrm{kg}^{-1}$ inhibited the activity of microorganisms in soil and thus limited the uptake of the substrate, the formation of the enzyme and the absorption of the generated product by microorganisms. Therefore, it is frequently accepted that dehydrogenases reflects the biological state of soil in the most exact manner (Wyszkowska et al. 2009; Ge and Zhang 2011). However, copper had a comprehensive effect on the enzymes, which is proven by the strong inhibition of urease activity, and urease is both an intraand extracellular enzyme, with as much as $80-90 \%$ of it being able to form complexes with soil colloids. It is significant that urease is one of the most frequently determined soil enzymes, because it largely affects the transformation of urea and what happens to it in arable land (Abalos et al. 2012). Wyszkowska et al. (2006), Ge and Zhang (2011) and Guo et al. (2012) also reported that $\mathrm{Cu}^{2+}$ is a strong inhibitor of urease. In turn, a study conducted by Castaldi et al. (2004) indicated that the activity of urease was not significantly correlated with the soil copper content.

The effect of copper on acid phosphatase and alkaline phosphatase was also negative, but this metal had a smaller inhibitory effect on these enzymes than on dehydrogenases and urease. Such behaviour of phosphatases is a consequence of their higher resistance to the action of copper than that of dehydrogenases and urease. This has been confirmed by studies conducted by other authors (Wang et al. 2009; Fernandez-Calvino et al. 2010b; Garcia-Gil et al. 2013). A smaller effect of copper on activity of acid phosphatase and alkaline phosphatase than of dehydrogenases and urease is a consequence of the fact that the contribution of phosphatases to soil metabolism is less than that of dehydrogenases and urease.
Regardless of the type of copper compound and the method of soil use and the type of enzyme, the greatest changes in enzymatic activity were observed in loamy sand. The mean $\mathrm{ED}_{50}$ in this type of soil was $293 \mathrm{mg} \mathrm{Cu}^{2+}$ $\mathrm{kg}^{-1}$ d.m. of soil, and it was significantly smaller in light loam, in which the mean $\mathrm{ED}_{50}$ was $413 \mathrm{mg} \mathrm{Cu}^{2+} \mathrm{kg}^{-1} \mathrm{~d} . \mathrm{m}$. of soil. The differences between $\mathrm{ED}_{50}$ for the soils are a consequence of a different content of organic carbon and colloidal silt, as well as sorptive capacity which in light loam is 1.8 times larger than in loamy sand (Table 1). Soil texture is one of the most important physical properties of soil, as it determines its biological activity; lumpy texture of soil is particularly desirable. Soils richer in organic carbon are characterised by greater enzymatic activity. They are less vulnerable to the adverse effects of a heavy metal but are more difficult to reclaim (Wyszkowska et al. 2013). Copper is strongly fixed in soil by silty minerals and organic matter, which plays a particularly significant role in soil fertility. Fixing $\mathrm{Cu}^{2+}$ cations by soil humus takes place through absorption, salt formation and, subsequently, through the formation of chelates, to formation of heterocyclic bonds (Kotrba et al. 2009). Soils with large sorptive capacity, with a high content of organic matter, with high levels of silt and dust, are much more capable of fixing copper. This was also observed in this study. Soils of low sorptive capacity are much less capable of fixing $\mathrm{Cu}^{2+}$ (Trasar-Capeda et al. 2000). Therefore, higher content of soil colloids, with consequent higher sorptive capacity of heavier soil, results in more effective copper fixing.

Differences in the impact on the enzymatic activity in the soil did not vary much from one copper compound to the other, because mean $\mathrm{ED}_{50}$ for copper(II) chloride was $341 \mathrm{mg} \mathrm{Cu}{ }^{2+} \mathrm{kg}^{-1}$ d.m. of soil, and for copper(II) sulphate(VI) - $364 \mathrm{mg} \mathrm{Cu}^{2+} \mathrm{kg}^{-1} \mathrm{~d}$.m. of soil. The differences in $\mathrm{ED}_{50}$ between the copper compounds can be attributed to the degree of their dissociation.

In order to make a comprehensive evaluation of the effect of soil contamination with copper on the stability of a soil ecosystem, one has to trace the reactions of different enzymes, both in unsown soil and in soil sown with different plants (Zaborowska et al. 2015). This was confirmed by the current study because the $\mathrm{ED}_{50}$ for dehydrogenases, urease and alkaline phosphatase was significantly lower in unsown soil than in soil sown with spring barley. It was completely different for acid phosphatase, although cultivation of spring barley in non-contaminated soil resulted in a highly significant increase in the activity of the enzyme. This may be attributed to the plant's ability to take up copper from the environment (Girotto et al. 2013). $\mathrm{Cu}^{2+}$ cations become fixed in a plant, and their effect on the soil biochemical properties is much weaker. Another noteworthy issue is the secretion of substances by roots, which precipitate copper in insoluble compounds. Plants can 
partly cope with abiotic stress by raising the level of salicylic acid, jasmonic acid, nitrogen oxide and ethylene. With increasing ethylene level, the activity of ACC (1-aminocyclopropane-1-carboxylic acid) in soil, which is responsible for its synthesis, also increases in soil contaminated with copper (Maksymiec et al. 2007). According to Wenhao et al. (2013), obtaining higher enzymatic activity in the rhizosphere layer encourages one to use plants as a phytoremediation agent.

The sensitivity of spring barley to copper compounds was lower than the enzymes under study. This was proven by the yield obtained on a plot in which soil was contaminated with $150 \mathrm{mg} \mathrm{Cu}^{2+} \mathrm{kg}^{-1}$ d.m. of soil, indicating that this level of contamination did not cause any significant changes in the development of the plant under study. The metabolism of plant cells was not disrupted until the doses of contamination reached a level of $300-600 \mathrm{mg}$ $\mathrm{Cu}^{2+} \mathrm{kg}^{-1}$ d.m. of soil. The effect was more pronounced in spring barley grown on loamy sand than on light loam. This can be explained logically because copper is strongly adsorbed by organic and mineral colloids, and there was more of both in light loam than in loamy sand. This is shown by the soil properties listed in Table 1 . There was more organic carbon and colloidal silt in loamy soil. Stronger adsorption of copper in light loam blocked part of the copper, preventing its direct effect on plant cells. This may result in a difference in copper's effect on spring barley in the two types of soil. A study conducted by Kucharski and Wyszkowska (2004) also showed that a toxic effect which involves disruption of water balance (wilting), chlorosis of young leaves and damaging of the apex and roots in spring barley was stronger in plants grown on leached brown soil formed from light loamy sand than on leached brown soil formed from light loam. Regardless of the physicochemical properties of soil, contamination of soil with copper has a negative effect of plant growth, disrupting electron transport and decreasing the rate of photosynthesis (Zhang et al. 2014) and results in a yield decrease (Wyszkowska et al. 2009; Girotto et al. 2013). When copper levels in soil increase and it is taken up by plants, it is fixed in roots by phytochelatins, and only small amounts are accumulated in the above-ground parts (Kotrba et al. 2009). However, this does not protect a plant against its toxic effect, which was confirmed in an experiment with spring barley.

The disruption of biological soil balance caused by an excessive level of copper (as observed in this study) can probably be attributed to upsetting the biological function, denaturation of proteins and damaging the cell membranes of soil microorganisms, with consequent disruption of soil metabolism. This study has shown that although an analysis of changes of activity of different soil enzymes can provide information on the trends and scale of transformations of the pedosphere, measurement of enzyme activity is not sufficient in the case of soil contamination with copper. This has to be supplemented with a plant test. Only these two tests combined can better explain disruptions in soil metabolism caused by excessive levels of copper.

\section{Conclusions}

An increase in the level of soil contamination with $\mathrm{Cu}^{2+}$ upsets its homeostasis, which is determined on the basis of the activity of soil enzymes, their resistance to copper, the level of $\mathrm{ED}_{50}$ as well as growth of spring barley. Dehydrogenases and urease were the most sensitive to contamination of soil with $\mathrm{Cu}^{2+}$, both as copper(II) chloride and as copper(II) sulphate(VI), while acid phosphatase and alkaline phosphatase were the least sensitive. Greater changes in enzymatic activity were observed in loamy sand than in light loam. The differences in the impact of copper(II) sulphate(VI) and copper(II) chloride on the soil microbiome were relatively small, because the mean $\mathrm{ED}_{50}$ for copper(II) chloride was $341 \mathrm{mg} \mathrm{Cu}{ }^{2+} \mathrm{kg}^{-1}$ d.m. of soil, and for copper(II) sulphate(VI) it was $364 \mathrm{mg} \mathrm{Cu}^{2+} \mathrm{kg}^{-1}$ d.m. of soil. This inhibitory effect of copper persisted throughout the period of the experiment. The sensitivity of spring barley to copper compounds was lower than the enzymes under study.

Acknowledgements Scientific research was financed by the Ministry of Science and Higher Education funds for statutory activity.

Open Access This article is distributed under the terms of the Creative Commons Attribution 4.0 International License (http://crea tivecommons.org/licenses/by/4.0/), which permits unrestricted use, distribution, and reproduction in any medium, provided you give appropriate credit to the original author(s) and the source, provide a link to the Creative Commons license, and indicate if changes were made.

\section{References}

Abalos D, Sanz-Cobena A, Misselbrook T, Vallejo A (2012) Effectiveness of urease inhibition on the abatement of ammonia, nitrous oxide and nitric oxide emissions in a non-irrigated Mediterranean barley field. Chemosphere 89:310-318

Alef K, Nannipieri P (1998) Urease activity. In: Alef K, Nannipieri P (eds) Methods in applied soil microbiology and biochemistry. Academic press, Harcourt Brace \& Company Publishers, London, pp 316-320

Alef K, Nannipieri P, Trasar-Cepeda C (1998) Phosphatase activity. In: Alef K, Nannipieri P (eds) Methods in applied soil microbiology and biochemistry. Academic press. Harcourt Brace \& Company Publishers, London, pp 335-344

Castaldi S, Rutigliano FA, Vtrzo De Santo A (2004) Suitability of soil microbial parameters as indicators of heavy metal pollution. Water Air Soil Pollut 158:21-35 
Ciarkowska K, Sołek-Podwika K, Wieczorek J (2014) Enzyme activity as an indicator of soil-rehabilitation processes at a zinc and lead ore mining and processing area. J Environ Manag 132:250-256

Fernandez-Calvino D, Martin A, Arias-Estevez M, Baath E, DiazRavina M (2010a) Microbial community structure of vineyard soils with different $\mathrm{pH}$ and copper content. Appl Soil Ecol 46:276-282

Fernandez-Calvino D, Soler-Rovira P, Polo A, Diaz-Ravina M, AriasEstevez M, Plaza C (2010b) Enzyme activities in vineyard soils long-term treated with copper-based fungicides. Soil Biol Biochem 42:2119-2127

Garcia-Gil JC, Kobza J, Soler-Rovira P, Javorekova S (2013) Soil microbial and enzyme activities response to pollution near an aluminium smelter. Clean Soil Air Water 41(5):485-492

Ge CR, Zhang QC (2011) Microbial community structure and enzyme activities in a sequence of copper-polluted soils. Pedosphere 21(2):164-169

Girotto E, Ceretta CA, Rossato LV, Farias JG, Tiecher TL, De Conti L, Schmatz R, Brunetto G, Schetinger MRC, Nicoloso FT (2013) Triggered antioxidant defense mechanism in maize grown in soil with accumulation of $\mathrm{Cu}$ and $\mathrm{Zn}$ due to intensive application of pig slurry. Ecotoxicol Environ Saf 93:145-155

Guo X, Gu J, Gao H, Qin Q, Chen Z, Shao L, Chen L, Li H, Zhang W, Chen S, Liu J (2012) Effects of Cu on metabolisms and enzyme activities of microbial communities in the process of composting. Bioresour Technol 108:140-148

Hu B, Liang D, Liu J, Xie J (2013) Ecotoxicological effects of copper and selenium combined pollution on soil enzyme activities in planted and unplanted soils. Environ Toxicol Chem 32(5):1109-1116

Kabata-Pendias A (2004) Soil-plant transfer of trace elements - an environmental issue. Geoderma 122(2-4):143-149

Kabata-Pendias A, Pendias H (2001) Trace elements in soils and plants, 3rd edn. CRC Press, Boca Raton, p 413

Khalil AH, Alquzweeni SS, Modhloom HM (2015) Removal of copper ions from contaminated soil by enhanced soil washing. Int J Environ Res 9(4):1141-1146

Kotrba P, Najmanova J, Macek T, Ruml T, Mackova M (2009) Genetically modified plants in phytoremediation of heavy metal and metalloid soil and sediment pollution. Biotechnol Adv 27:799-810

Kucharski J, Wyszkowska J (2004) Inter-relationship between number of microorganisms or spring barley yield and degree of soil contamination with copper. Plant Soil Environ 50(6):243-249

Kungolos A, Emmanouil C, Tsiridis V, Tsiropoulos N (2009) Evaluation of toxic and interactive toxic effects of three agrochemicals and copper using a battery of microbiotests. Sci Total Environ 407(16):4610-4615

Maksymiec W, Wójcik M, Krupa Z (2007) Variation in oxidative stress and photochemical activity in Arabidopsis thaliana leaves subjected to cadmium and excess copper in the presence or absence of jasmonate and ascorbate. Chemosphere 66:421-427

Ngole VM, Ekosse GIE (2012) Copper, nickel and zinc contamination in soils within the precincts of mining and landfilling environments. Int J Environ Sci Technol 9:485-494

Öhlinger R (1996) Dehydrogenase activity with the substrate TTC. In: Schinner F, Öhlinger R, Kandeler E, Margesin R (eds) Methods in soil biology. Springer, Verlag, pp 241-243

Orwin KH, Wardle DA (2004) New indices for quantifying the resistance and resilience of soil biota to exogenous disturbances. Soil Biol Biochem 36:1907-1912

StatSoft, Inc (2015) STATISTICA (data analysis software system), version 12,5 . www.statsoft.com
Tica D, Udovic M, Lestan D (2011) Immobilization of potentially toxic metals using different soil amendments. Chemosphere $85: 577-583$

Trasar-Capeda C, Leiros MC, Seoane S, Gil-Sotres F (2000) Limitations of soil enzymes as indicators of soil pollution. Soil Biol Biochem 32:1867-1875

Tripathy S, Bhattacharyya P, Mohapatra R, Som A, Chowdhury D (2014) Influence of different fractions of heavy metals on microbial ecophysiological indicators and enzyme activities in century old municipal solid waste amended soil. Ecol Eng 70:25-34

Wang YP, Shi JY, Wang H, Lin Q, Chen XC, Chen YX (2007) The influence of soil heavy metals pollution on soil microbial biomass, enzyme activity, and community composition near a copper smelter. Ecotoxicol Environ Saf 67:75-81

Wang QY, Zhou DM, Cang L (2009) Microbial and enzyme properties of apple orchard soil as affected by long-term application of copper fungicide. Soil Biol Biochem 41:1504-1509

Wang F, Yao J, Si Y, Chen H, Russel M, Chen K, Qian Y, Zaray G, Bramanti E (2010) Short-time effect of heavy metals upon microbial community activity. J Hazard Mater 173:510-516

Wenhao Y, Hong H, Mei R, Wuzhong N (2013) Changes of microbial properties in (near) rhizosphere soils after phytoextraction by Sedum alfredii $\mathrm{H}$ : A rhizobox approach with an artificial $\mathrm{Cd}-$ contaminated soil. Appl Soil Ecol 72:14-21

Wightwick AM, Mollah MR, Partington DL, Allinson G (2008) Copper fungicide residues in Australian vineyard soils. J Agric Food Chem 56:2457-2464

Word Reference Base of Soil Resources (2014) A framework for international classification, correlation and communication. Word soils resources report. 103. FAO, Rome

Wyszkowska J, Kucharski J, Lajszner W (2006) The effects of copper on soil biochemical properties and its interaction with other heavy metals. Pol J Environ Stud 15(6):927-934

Wyszkowska J, Kucharski M, Kucharski J, Borowik A (2009) Activity of dehydrogenases, catalase and urease in copper polluted soil. J Elementol 14(3):605-617

Wyszkowska J, Borowik A, Kucharski J (2013) Effect of cadmium, copper and zinc on plants, soil microorganisms and soil enzymes. J Elementol 18(4):769-796

Wyszkowski M, Wyszkowska J (2009) The effect of contamination with cadmium on spring barley (Hordeum vulgare L.) and its relationship with the enzymatic activity of soil. Fresen Environ Bull 18(7):1046-1053

Yang ZX, Liu SQ, Zheng DW, Feng SD (2006) Effects of cadmium and lead on soil enzyme activities. $J$ Environ Sci 18(6):1135-1141

Zaborowska M, Kucharski J, Wyszkowska J (2015) Using basalt flour and brown algae to improve biological properties of soil contaminated with cadmium. Soil Water Res 10(3):181-188

Zhan J, Sun QY (2014) Development of microbial properties and enzyme activities in copper mine wasteland during natural restoration. CATENA 116:86-94

Zhang FP, Li CF, Tong LG, Yue LX, Li P, Ciren YJ, Cao CG (2010) Response of microbial characteristics to heavy metal pollution of mining soils in central Tibet, China. Appl Soil Ecol 45:144-151

Zhang W, Zhang M, An S, Lin K, Li H, Cui C, Fu R, Zhu J (2012) The combined effect of decabromodiphenyl ether (BDE-209) and copper $(\mathrm{Cu})$ on soil enzyme activities and microbial community structure. Environ Toxicol Pharm 34:358-364

Zhang L, Pan Y, Lv W, Xiong ZT (2014) Physiological responses of biomass allocation, root architecture, and invertase activity to copper stress in young seedlings from two populations of Kummerowia stipulacea (maxim.) Makino. Ecotoxicol Environ Saf 104:278-284 